\title{
Barriers to participation in clinical trials: cross-sectional study on perceptions of oncology patient advocacy group webpage in Brazil
}

Barreiras à participação em ensaios clínicos: estudo transversal sobre as percepções do grupo de defesa à pacientes oncológicos em uma página da internet no Brasil

Guilherme Silva Julian ${ }^{1}$, Christiane Bueno², Renata Eiras Martins³, Luciana Holz Camargo de-Barros ${ }^{1}$

\begin{abstract}
Introduction: Clinical trials (CT) represent an important alternative treatment for oncologic patients. Also, CTs represent an essential step to development of improved therapeutic strategies. However, little is known on Brazilian perception regarding CT. The aim of this survey was to describe the overall perception of CT in Brazilian participants of oncology patient advocacy group. Design and setting: Cross-sectional survey conducted online through patient advocacy group website. Methods: From April 2012 to October 2014, 254 respondents answered an internet-based survey related to knowledge on CT from an independent nonprofit oncology patient advocacy group. Results: Overall, about $85 \%$ of respondents stated they would participate in an oncology trial. Of all respondents, 99.9\% believe that CTs can contribute positively to advancement of cancer treatment by increasing the scientific knowledge, improving the treatment, finding a cure, providing a new treatment option, or improving the quality of life. Also, $96 \%$ affirmed they have already had some information on $\mathrm{CT}$, being internet the most used form of communication $(69 \%)$, followed by physicians orientation $(8 \%)$, magazines and newspaper (8\%), and hospital handout material (7\%). In addition, only 18 respondents reported previously participation in CTs (6.9\%), and approximately $10 \%$ answered they knew someone that participated in a CT (e.g. friend or other). Conclusions: This survey demonstrated that respondents associate $\mathrm{CT}$ as an option in cancer treatment; however, only a small number of respondents have participated in a CT previously. The data indicate the lack of available information as the current major barrier to CT participation in Brazil.
\end{abstract}

Keywords: Clinical trial; Patient advocacy; Awareness; Physician-Patient relations; Health surveys.

\footnotetext{
1. Instituto Oncoguia, Instituto Oncoguia - São Paulo - SP - Brazil

2. Kantar Health, Communication - São Paulo - SP - Brazil

3. Instituto Oncoguia, Instituto Oncoguia - São Paulo - SP - Brazil

Financial support: none to declare.

Conflicts of interest: The authors declare no conflict of interest relevant to this manuscript.

Correspondence author: Luciana Holz Camargo de-Barros. Instituto Oncoguia, Instituto Oncoguia - São Paulo - SP - Brazil

Email: lucianaholtz@oncoguia.org.br
}

Received on: February 22, 2019 | Accepted on: July 4, 2019

DOI: $10.5935 / 2526-8732.20190016$ 


\section{RESUMO}

Introdução: Os ensaios clínicos (EC) representam uma alternativa importante no tratamento de pacientes oncológicos Além disso, ECs representam um passo essencial para o desenvolvimento de estratégias terapêuticas aprimoradas. No entanto, pouco se sabe sobre a percepção dos brasileiros em relação ao EC. O objetivo desta pesquisa foi descrever a percepção geral do EC em participantes brasileiros do grupo de defesa à pacientes oncológicos. Tipo de estudo e local: Pesquisa transversal realizada on-line através de um site do grupo de defesa à pacientes. Métodos: De abril de 2012 a outubro de 2014, 254 entrevistados responderam a uma pesquisa na Internet de uma organização independente sem fins lucrativos de defesa à pacientes oncológicos, relacionada ao conhecimento sobre EC. Resultados: No geral, cerca de $85 \%$ dos entrevistados afirmaram que participariam de um estudo oncológico. De todos os entrevistados, 99.9\% acreditam que ECs podem contribuir positivamente no avanço do tratamento do câncer, aumentando o conhecimento científico, melhorando o tratamento, encontrando uma cura, proporcionando uma nova opção de tratamento ou melhorando a qualidade de vida. Além disso, 96\% afirmaram que já possuíam alguma informação sobre EC, sendo a Internet a forma de comunicação mais utilizada (69\%), seguida de orientação médica (8\%), revistas e jornais (8\%) e folheto em hospital (7\%). Além disso, apenas 18 entrevistados relataram participação prévia em ECs (6.9\%) e, aproximadamente 10\%, responderam conhecer alguém que participou de um EC (por exemplo, amigo ou outro). Conclusão: Esta pesquisa demonstrou que os entrevistados associam EC como uma opção no tratamento do câncer; no entanto, apenas um pequeno número de entrevistados participou anteriormente de um EC. Os dados indicam a falta de informação disponível como a maior barreira atual à participação de EC no Brasil.

Descritores: Ensaio clínico; Defesa do paciente; Conscientização; Relações médico-paciente; Pesquisas de saúde.

\section{INTRODUCTION}

Cancer treatment clinical trials are essential for developing new therapies and ensuring they become available to all patients in need. When participating in a clinical trial (CT), a patient plays an important and active role in this development, where he/she can have access to potentially helpful treatments before they are available to the general public, being also able to help other people by improving cancer care.

Patients' decisions regarding participating or not in a CT may be influenced by the information they receive. Worries related to placebo use, decrease in quality of life and lack of awareness on $C T$ by the general population are among the main barriers to CT recruitment. ${ }^{1-3}$ Despite these concerns, $40 \%$ of patients would still accept to participate in a $\mathrm{CT}^{4}$ On the other hand, previous studies have shown that patients can have misconceptions about aspects of research, such as the risk of adverse events, the trial's aims and the likelihood of personal benefit. 5 This may lead to the low participation in CT: approximately $3 \%$ of adult cancer patients participate in clinical trials in the US. This indicates a clear gap between willingness to participate and effective participation in CTs.
Understanding the main barriers to patient's recruitment is essential to improve enrollment strategies and health access through $\mathrm{CT}$, especially in severe diseases, as cancer. A better understanding of patients' motivations for participating in cancer research and their opinions of CT information and the consent process may lead to changes that facilitate trial recruitment and improve patient satisfaction with the recruitment process. Patient groups have an important role in patient's awareness, including adverse events and treatment options - and this comprises CTs. Thus, they are an essential tool to help in the recruitment of patients to CTs.

In Brazil, lack of information on clinical research may impair participation in CT. Therefore, this study aims to identify the main barriers to CT participation, source of information regarding $C T$, and evaluate CT awareness levels in followers of the webpage of Oncoguia Institute, a Brazilian independent non-profit institution, with the mission of helping cancer patients to live better. By identifying gaps and barriers in of oncology patient advocacy group participants' knowledge, Oncoguia can plan strategies and online actions aiming patient education improvement. 


\section{METHODS}

\section{Study design}

This was an internet-based survey related to knowledge related clinical research from Oncoguia Institute was available on the Institute's website, available online from April 2012 until October 2014. The primary objective of the study was to identify the level of knowledge on CT in Oncoguia's website users. The study population was defined as all people with internet access that follow Oncoguia's webpage (15 million accesses/year) or Facebook page (more than 220,000 followers).

This study was conducted according to the Brazilian regulation on anonymized surveys (Resolution number 510 of 2016), which absolves surveys of personal opinion with anonymized participants of approval in Institutional Ethics Committees. Also, the survey page asked the participant if they consent to participate in the research. We did not collect any identification of the respondents; so, collected data were fully anonymized in order to ensure respondents confidentiality and privacy.

\section{Questionnaire}

In order to achieve the objectives of the study, we developed an online survey questionnaire of easy comprehension in Brazilian Portuguese, separated in CT definition for the respondent; sources of knowledge regarding CT; CT's role in advances of cancer treatment; wiliness to participate in a CT; and, knowledge on any CT participation of any known person. The full questionnaire is available in Brazilian Portuguese and translated into English in Appendix 1.

\section{Data analysis}

This is a descriptive study with the aim of describe the population characteristics and generate hypothesis. Survey responses were extracted, with counting/ranking for those related to multiple-choice and categorization for those related to open-answer questions. Subsequently, all outcomes were be summarized. In the description of data defined as categorical variables were described by simple and cross contingency tabulation, with absolute frequencies and percentages. All results are reported as the rate of respondents with multiple choices for several questions.

\section{RESULTS}

From April 2012 until October 2014, 254 respondents answered the survey. In respondents' opinion, clinical research was defined as "research to improve cancer treatment" (47.1\%), "clinical investigation" (22.0\%), and "cure" (15.9\%), while $13.6 \%$ did not know the definition of clinical research, $1.0 \%$ claimed lack of information, and $0.3 \%$ gave inconclusive answers.

The massive majority of respondents (69\%) had internet as source of information regarding clinical research, followed by newspapers and magazines (8\%), physician's orientation (8\%), hospital informative material $(7 \%)$, other healthcare professionals (3\%), TV or radio (2\%), other patients (2\%), and informative leaflets (1\%). Almost all respondents (99.6\%) believe that clinical research can contribute to advances in cancer treatment, and the reasons for that were: increasing the scientific knowledge (53.4\%); improvement in quality of life (53\%); seeking the cure (48.2\%); improvement of the treatment (42.9\%); and, finding novel treatment options (42.9\%).

Regarding participation in CTs, $85 \%$ of the respondents would accept to participate. The main reasons for accepting to participate or not are described in Table 1. Among the respondents, only $20.1 \%$ knew someone who participated in a CT, of which in $44.2 \%(n=18)$ of the cases the respondent himself has already participated in a clinical trial.

\section{DISCUSSION}

Clinical trials are a crucial step in advancing new treatments for the cancer care. Thus, a thorough understanding of patient recruitment patterns and barriers to CT is of paramount importance.

Also, it is imperative to observe that patients can access the latest advancements in cancer treatment through CTs. This is especially relevant in low- and middle-income countries, where the burden of cancer care is increased, and new technologies are not available or not affordable. Thus, expanding participation in $\mathrm{CT}$ may be a way to access cuttingedge medications that would otherwise not be covered by these healthcare systems.
Several studies have shown that, even though patients are inclined to participate in clinical trials, very few do so. ${ }^{4,7,8}$ Therefore, there is a large gap between the patients' willingness to participate in a CT and the actual participation rates, suggesting that barriers to $\mathrm{CT}$ participation are numerous and frequently insuperable.

In our study, results showed that overall about 85\% of respondents would participate in a cancer trial. Of all respondents, 99.9\% believe that clinical research can contribute positively to the advancement of cancer treatment and 96\% affirmed that have already had some information on clinical research. On the other hand, only $6.9 \%$ of respondents reported previously participation on CT, and about 10\% answered that they knew someone who participated in a CT (e.g. friend, family or other). 
Table 1. Patient's reasons to participate or not in clinical trials

\begin{tabular}{|c|c|}
\hline Reasons to participate or not in clinical trials & Patients* (\%) \\
\hline \multicolumn{2}{|l|}{ Reasons to participate in clinical trials } \\
\hline Improvement in treatment / Cure & $103(47.2)$ \\
\hline Personal experience/motivation & $71(32.6)$ \\
\hline Help to other patients & $66(30.3)$ \\
\hline Would participate if ensured that the trial would not add any additional risk & $12(5.5)$ \\
\hline Access to novel treatments & $8(3.7)$ \\
\hline Clinical trial subject & $5(2.3)$ \\
\hline Special interest in the subject/Prevention & $5(2.3)$ \\
\hline \multicolumn{2}{|l|}{ Reasons NOT to participate in clinical trials } \\
\hline Lack of information & $11(32.4)$ \\
\hline Lack of opportunity & $10(29.4)$ \\
\hline Fear & $5(14.7)$ \\
\hline Consider their treatment well studied & $4(11.8)$ \\
\hline Inconclusive & $2(5.9)$ \\
\hline Negative past experiences & $1(2.9)$ \\
\hline
\end{tabular}

*Patients answers were categorized from open-answer; Patients' answer could fulfill more than one reason.

The data indicate that lack of available information, including low participation of physician on instructing their patients, are the current major barriers on $\mathrm{CT}$ in Brazil. This is in line with recent discussions on the same subject, which are few worldwide. ${ }^{10,11}$ Currently, the treatment decision-making process based on the patient's perspective receives more and more emphasis. Patient-centered medicine is practice with patients participating in their own healthcare decisions and in researches informing such decisions. ${ }^{12}$ Therefore, giving the opportunity and the necessary tools for patients to make a well-informed decision to participate or not in CTs is vital. ${ }^{8}$ Improvements in patient understanding of trial methodology and patient safety could improve interest in and recruitment to CTs.

In this scenario, the role of patient groups is fundamental. Patients' groups provide oriented education, advocacy, and support services, playing an important role in patient's perspective, increasing quality of life, emotional support and other outcomes. ${ }^{13}$ In oncology, theyalso help understanding patients' needs and disease awareness, which may improve prevention, early detection, quality-oflife and legal rights, reducing the burden of the disease. Hence, these groups are of paramount importance in educating and raising patients' awareness regarding $\mathrm{CT}$, thus contributing to filling the gap between willingness to participate and actual participation in cancer trials.
Information is a valuable tool in cancer care, and patient groups are important - and reliable - vehicles for disseminating this information. Thus, they can be an effective communication channel on cancer trials, clarifying patients' doubts, informing them about new researches, and even referring patients to CTs that best fit their condition. Cancer patient groups worldwide engage in the design of CTs and tackle the inequalities of access to treatment and information. They are important tools for patients to gain access to medicines, and also in the development of CTs, influencing their design and helping to increase their accrual.'

To date, little is known about Brazilian patient's perception regarding CT. This study sought to describe the overall perception of patients on clinical research in Brazil and showed that lack of information impairs patients' participation in cancer trials. Despite its limitations, such as low participation rate, recruitment only among Oncoguia's website users, absence of gender and tumor specification, it presented preliminary data that can be useful for planning and developing strategies for recruiting participants to CTs, as well as for the design of studies themselves. It also shows that a crucial component for increasing accrual should focus on the process of informing and educating patients about clinical research - a role that must be played by patients' advocacy groups too.

\section{CONCLUSION}

This survey, even with its limitations aforementioned, demonstrates that respondents associate clinical research as an option in cancer treatment. However, only a small number of respondents have participated previously in a CT. Besides, the internet was the main tool to learn about CTs. The data indicate that lack of available information, including low participation of physician on instructing their patients, are the current major barriers on CT in Brazil on patient perspective. Besides the improvements needed on regulation and approval timelines, on patient/CT subject perspective, the improvement of physician and patient awareness are potential solutions. Thus, strategies are needed to improve communication between patient and physician. 


\section{AUTHOR'S CONTRIBUTION}

Guilherme Silva Julian: Conception and design, Data analysis and interpretation, Final approval of manuscript, Manuscript writing.

Christiane Bueno: Data analysis and interpretation, Final approval of manuscript, Manuscript writing.
Renata Eiras Martins: Final approval of manuscript, Manuscript writing.

Luciana Holz Camargo de-Barros: Data analysis and interpretation, Final approval of manuscript, Manuscript writing, Provision of study materials or patient.

\section{REFERENCES}

1. Cameron P, Pond GR, Xu RY, Ellis PM, Goffin JR. A comparison of patient knowledge of clinical trials and trialist priorities. Curr Oncol. 2013 Jun;20(3):e193-e205. DOI: 10.3747/co.20.1323

2. Mills EJ, Seely D, Rachlis B, Griffith L, Wu P, Wilson K, et al. Barriers to participation in clinical trials of cancer: a meta-analysis and systematic review of patient- reported factors. Lancet Oncol. 2006 Feb;7(2):141-8. DOI: 10.1016/S14702045(06)70576-9

3. Bazarbashi S, Hassan A, Eldin AM, Soudy H, Hussain F. Awareness and perceptions of clinical trials in cancer patients and their families in Saudi Arabia. J Cancer Educ. 2015 Dec;30(4):6559. DOI: 10.1007/s13187-015-0797-0

4. Comis RL, Miller JD, Aldigé CR, Krebs L, Stoval E. Public attitudes toward participation in cancer clinical trials. J Clin Oncol. 2003 Mar;21(5):830-5. DOI: 10.1200/JCO.2003.02.105

5. Gehan EA. Clinical trials in cancer research. Environ Health Perspect. 1979 Oct;32:31-48. DOI: 10.1289/ehp.793231

6. JoffeS, CookEF, ClearyPD, ClarkJW, WeeksJC. Quality of informed consent in cancer clinical trials: a crosssectional survey. Lancet. 2001 Nov;358(9295):17727. DOI: $10.1016 /$ S0140-6736(01)06805-2

7. Institute of Medicine (US) Forum on Drug Discovery, Development, and Translation. Clinical Trials in Cancer. Transforming clinical research in the United States: challenges and opportunities. Washington (DC): National Academies Press (US); 2010.

8. Unger JM, Cook E, Tai E, Bleyer A. Role of clinical trial participation in cancer research: barriers, evidence, and strategies. Am Soc Clin Oncol Educ Book. 2016;35:185-98. DOI: 10.14694/ EDBK_156686
9. Lopes Junior GL, Souza JA, Barrios C. Access to cancer medications in low- and middle-income countries. Nat Rev Clin Oncol. 2013Jun;10(6):31422. DOI: $10.1038 /$ nrclinonc. 2013.55

10. Goss PE, Lee BL, Badovinac-Crnjevic T, StrasserWeippl K, Chavarri-Guerra Y, St Louis J, et al. Planning cancer control in Latin America and the Caribbean. Lancet Oncol. 2013 Apr;14(5):391436. DOI: 10.1016/S1470-2045(13)70048-2

11. Strasser-Weippl K, Chavarri-Guerra Y, VillarrealGarza C, Bychkovsky BL, Debiasi M, Liedke $P E$, et al. Progress and remaining challenges for cancer control in Latin America and the Caribbean. Lancet Oncol. 2015 Oct;16(14):140538. DOI: 10.1016/S1470-2045(15)00218-1

12. Tinetti $M E$, Basch $E$. Patients' responsibility to participate in decision making and research. JAMA. 2013 Jun;309(22):2331-2. DOI: 10.1001/ jama.2013.5592

13. Ahlberg $K$, Nordner A. The importance of participation in support groups for women with ovarian cancer. Oncol Nurs Forum. 2006 Jul;33(4):E53-61. DOI: 10.1188/06.ONF.E53-E61

14. Till JE. Evaluation of support groups for women with breast cancer: importance of the navigator role. Health Qual Life Outcomes. 2003 May;1:16. DOI: $10.1186 / 1477-7525-1-16$

15. Fricker J. Patient advocacy groups: empowering patients in their fight against cancer. Mol Oncol. 2007 Dec;1(3):252-4. DOI: 10.1016/j. molonc.2007.08.003

16. Hall MJ, Egleston B, Miller SM, Buzaglo JS, Millard J, Ridgway $C$, et al. Barriers to participation in cancer prevention clinical trials. Acta Oncol. 2010 Aug;49(6):757-66. DOI: 10.3109/0284186X.2010.485209 


\section{APPENDIX 1}

\section{Questionnaire applied (in Brazilian Portuguese)}

- $\quad$ O que é pesquisa clínica para você?

- Como soube da pesquisa clínica?

- Você acha que a pesquisa clínica contribui para o avanço do tratamento do câncer?

- $\quad$ Se sim, de que maneira?

- Aumento do conhecimento científico

- Melhora do tratamento

- Busca da cura

- Melhora da qualidade de vida

- Para ter uma nova opção de tratamento

- Você participaria de uma pesquisa clínica em câncer?

- Se sim, por que?

o Se não, por que?

- Você conhece alguém que já participou de uma pesquisa clínica em câncer?

o Se sim, quem?

\section{Questionnaire translated to English}

- In your opinion, what is clinical research?

- How did you know about clinical research?

- Do you think clinical research contributes to advances of cancer treatment?

- If yes, in which manner(s)?

口 Increase of scientific knowledge

Treatment improvement

$\square \quad$ Seeking cure

․ Improvement in quality of life

$\square \quad$ To be a novel treatment option

- Would you participate in a clinical trial in cancer?

o If yes, why?

o If not, why?

- Do you know anyone that already parcipated in a cancer clinical trial?

o If yes, who? 